\title{
Mniejszość polska w odrodzonej Łotwie
}

\section{Polish minority in reborn Latvia}

\author{
Monika Michaliszyn \\ ZAKŁAD BAŁTYSTYKI, UNIWERSYTET WARSZAWSKI, KRAKOWSKIE PRZEDMIEŚCIE \\ OO-927 WARSZAWA \\ m.michaliszyn@uw.edu.pl
}

\begin{abstract}
This article concerns the least-described period in the literature on the subject of the history of Latvian Poles - the time after Latvia regained its independence. The national movement strangled after the incorporation of the Republic of Latvia into the USSR for fifty years was cultivated illegally most often in the so-called Polish houses. The nucleus of Polish organizations established with the consent of the authorities in the end of the 1970s laid the foundations of the Association of Poles in Latvia ZPE) on the turn of independence at the turn of 1980 s. Soon, a dozen of his branches were created. The ZPŁ is actively working to cultivate Polishness and propagate Polish culture. Thanks to his activities, a Polish school network was established in Latvia. Problems included in the work are presented in the historical and cultural perspective. A large part of the information presented is the result of a record of interviews with representatives of the Polish community and the result of the use of rich online resources illustrating the dynamic process of life of contemporary Poles in Latvia.
\end{abstract}

\section{Wprowadzenie}

$\mathrm{Na}$ początku lat dziewięćdziesiątych jeden z najbardziej znaczących badaczy tematyki polsko-łotewskiej, Jacek Kolbuszewski, konstatował, że o losie, przeszłości i współczesnych problemach Polaków na Łotwie wiadomo w Polsce bardzo mało. Tematyka ta, według badacza, nie była do ówczesnego momentu przedmiotem systematycznych badań, a podejmowano ją raczej okazjonalnie, na marginesie innych zagadnień (Kolbuszewski 1991, 331). 


\section{Monika Michaliszyn: Mniejszość polska w odrodzonej Łotwie}

Okres wolności obu krajów sprzyjał rozwojowi studiów nad polską społecznością na Łotwie. Powstające w tym okresie prace obejmują szerokie spektrum życia łotewskich Polaków. W większości dotyczą raczej wybranych zagadnień (m.in. szkolnictwo polskie na Łotwie), są ograniczone do wybranego terytorium (najczęściej jest to Dyneburg lub szerzej - Łatgalia, zapewne ze względu na najliczniejszą grupę Polaków zamieszkujących te tereny, ale także Jełgawa) lub też okresu historycznego (międzywojnie) ${ }^{1}$. Tak szkolnictwo polskie na Łotwie, jak i łatgalscy Polacy doczekali się studiów opracowanych $\mathrm{w}$ oparciu o badania socjologiczne ${ }^{2}$. Powstała monografia poświęcona literaturze i kulturze tworzonej przez Polaków nad Dźwiną, zarówno w wieku XIX, jak i w I połowie XX w. ${ }^{3}$ Niezaprzeczalną wartość badawczą, pomimo upływu lat, ma tom wydany w 1993 r. pod redakcją ks. E Walewandera pt. Polacy na Łotwie4, będący kompendium wiedzy o polskiej obecności na Łotwie w ujęciu historyczno-kulturowym. Analogiczną pracą w zakresie obecności kultury polskiej na terenach Łotwy jest zbiór artykułów polskich i łotewskich badaczy pt. Kultura polska na Łotwies. Aktualności nie traci też wydana na początku lat dziewięćdziesiątych praca łotewskiego historyka E. Jēkabsonsa, omawiająca obecność Polaków na Łotwie wielaspektowo (historia, kultura, preferencje polityczne, wskaźniki demograficzne), pt. Poḷi Latvija ${ }^{6}$. Ujęcie z pogranicza socjologii i kultury prezentuje praca T. Biernata Być Polakiem na Łotwie, ukazująca Polaków na Łotwie przez pryzmat potocznego rozumienia polskości i jej istoty7.

Obraz stanu badań nad obecnością polskiej kultury na Łotwie prowadzonych w różnych ośrodkach naukowych w Polsce dają wreszcie kolejne tomy serii Stan badań nad wielokulturowym dziedzictwem dawnej Rzeczypospolitej ${ }^{8}$ pod redakcją W. Walczaka i K. Łopateckiego.

\footnotetext{
${ }^{1}$ Monografie prezentujące diasporę polską w okresie międzywojennym: J. Albin, Polski ruch narodowy na Łotwie $w$ latach 1919-1940, Wrocław 1993. A. Durejko, Polskie życie kulturalne $i$ literackie $w X X w$., Wrocław 2001.

2 Rozprawy dotyczące Polaków w Łatgalii to: Polacy nad Dźwina, red. M. Fuszara, J. Kurczewski, Warszawa 2007; oraz J. Kurczewski, V. Volkovs, The Latvians, Russians and Poles of Present Day Daugavpils, Rīga 2012. Szkolnictwo polskie na Łotwie, głównie w perspektywie losów Szkoły Polskiej im. Ity Kozakiewicz w Rydze, ukazuje książka autorstwa M. M. Urlińskiej, Szkoła polska na obczyźnie wobec dylematów tożsamościowych, Toruń 2007. Badania nad ludnością Łotwy prowadził P. Eberhardt, zob. P. Eberhardt, Problematyka narodowościowa Łotwy, Warszawa 1998. Obecność polską w Kurlandii opisał A. Janicki w dziele pt. Kurlandia w latach 1795-1915, Gdańsk 2012. Obecność polską w Rydze (głównie na Politechnice Ryskiej) badali A. Janicki, E. Jekabsons, M. Laszczkowski, zob. tychże Polentechnikum, Warszawa 2012; oraz M. Laszczkowski, Welecja. Dzieje korporacji, Warszawa 2013. Ziemi piltyńskiej swe studia poświęcił B. Dybaś, Na obrzeżach Rzeczypospolitej. Sejmik piltyński w latach 1617-1717, Toruń 2004. Krótki okres przynależności Rygi do Polski opisała A. Ziemlewska w książce Ryga w Rzeczypospolitej Polsko-Litewskiej, Toruń 2008. Tematyce polskiej spuścizny na Łotwie poświecone były publikacje, których autorem lub redaktorem był J. Sozański, m.in. MojeInflanty, Toruń 2004,

3 Należą do nich publikacje D. Samborskiej-Kukuć, Polski Inflantczyk Kazimierz Bujnicki, Kraków 2008; K. Zajas, Nieobecna kultura. Przypadek Inflant Polskich, Kraków 2008, oraz A. Durejko, Polskie wiersze nad Dźwina, Wrocław 1994.

4 Polacy na Łotwie, red. E. Walewander, Lublin 1993.

${ }^{5}$ Kultura polska na Łotwie, red. J. Sozański, R. Szklennik, Ryga 1994.

6 E. Jēkabsons, Poḷi Latvijā, Rīga 1996.

7 T. Biernat, Być Polakiem na Łotwie. Świat życia codziennego, Toruń 2003.

8 Zob. Stan badań nad wielokulturowym dziedzictwem Rzeczypospolitej, t. 1, 2, red. W. Walczak, K. Łopatecki, Białystok 2010; t. 4, red. W. Walczak, K. Łopatecki, Białystok 2013. W całości tematyce
} 
W 2016 r. ukazała się pozycja K. Leśniewskiej- Napierały pt. Geograficznopolityczne uwarunkowania sytuacji mniejszości polskiej na Litwie $i$ Łotwie po 1990 r., przedstawiająca tematykę łotewskich Polaków w jako współczesnej mniejszości narodowej (od 1990 r.). Niedocenianym przez badaczy źródłem wiedzy o łotewskiej mniejszości polskiej jest również wydawany przez Związek Polaków na Łotwie od 1991 r. „Polak Na Łotwie”. Wiele cennych informacji przynosi także portal internetowy „Przegląd Bałtycki”, którego autorzy (m. in. T. Otocki, M. Jankowiak, A. Smarzewska) sięgają po tematykę łotewską. Na jego łamach swoje artykuły publikują także przedstawiciele łotewskiej Polonii (m.in. Krystyna Kuņicka9).

Niniejszy artykuł dotyczy najmniej bodaj opisanego w literaturze przedmiotu okresu historii łotewskich Polaków - czasów po odzyskaniu niepodległości przez Łotwę. Ze względu na obszerność tematu jest to bardziej zarys tematyki z wykorzystaniem najnowszych źródeł w języku polskim i łotewskim, a także zasobów Internetu ${ }^{10}$. Ujęte w pracy problemy przedstawione zostały w perspektywie historyczno-kulturowej. Znaczna część przedstawionych informacji jest rezultatem wiedzy zebranej podczas pięcioletniego pobytu autorki na Łotwie, zapisem wywiadów autorki z przedstawicielami polskiej społeczności oraz wynikiem wykorzystania zasobów internetowych, obrazujących dynamiczny proces życia współczesnych Polaków na Łotwie. ${ }^{112}$

\section{Okres powojenny}

Wojna i ucieczka wielu łotewskich Polaków do Polski w obliczu ponownego wkroczenia Armii Czerwonej nie przyniosły znaczących zmian

obecności polskiej na Łotwie poświęcony jest tom 3, zatytułowany Inflanty Polskie, red. W. Walczak, K. Łopatecki, Białystok 2012.

K. Kunicka jest jedną z najbardziej aktywnych i najlepiej wykształconych przedstawicieli młodego pokolenia łotewskich Polaków. W 2017 roku obroniła na Uniwersytecie w Daugavpils pracę doktorską pt., Latgales poḷu valoda kā poḷu valodas periferiālais dialekts: paaudžu atšḳirību aspekts" (Język polski w Łatgalii jako dialekt peryferyjny języka polskiego: w aspekt odrębności pokoleniowych). Jest członkiem zarządu dyneburskiego oddziału ZPŁ „Promień” Komitetu Doradczego Organizacji Pozarządowych Mniejszości Narodowych przy Ministerstwie Kultury Łotwy. Zob. także T. Otocki: Teraz nie ma już w Dyneburgu takiego entuzjazmu dla polskości. Wywiad z K. Kunicka: $\quad$ http://zw.lt/opinie/krystyna-kunicka-teraz-juz-nie-ma-w-dyneburgu-takiegoentuzjazmu-dla-polskosci/ [data dostępu: 15.07.2017].

${ }^{10}$ Coraz cenniejsze wydają się źródła internetowe, niejednokrotnie umożliwiają one bowiem dotarcie do najnowszych zbiorów archiwów na świecie, jak choćby w przypadku dokumentów dysydenta polskiego pochodzenia Jana Jachimowicza (łot. Jānis Jahimovičs), nabytych i udostępnionych w październiku 2016 r. przez Archiwum Hoovera, zob.: http://www.hoover.org/news/hoover-archivesacquires-papers-latvian-dissident-janis-jahimovics.

${ }^{11}$ Młodsze pokolenie Polaków komunikuje się ze sobą w większości poprzez facebookową stronę Związku Młodych Polaków na Łotwie. W prowadzonych na stronie dyskusjach uczestniczą nie tylko członkowie ZMPŁ, ale i osoby zainteresowane życiem polskiej diaspory na Łotwie, wymieniane i komentowane są tam również wydarzenia z życia Polonusów, przez co strona ta staje się cenną dla badacza kroniką.

12 Problematyczne pozostaje wciąż zapis nazwisk oraz imion łotewskich Polaków, które pojawiają się w źródłach w wariancie polskim lub łotewskim. Czasem zapis występuje tylko w wariancie polskim lub tylko łotewskim. Autor artykułu zastosował kryterium częstotliwości występowania danego wariantu zapisu nazwiska w materiałach źródłowych. 
w stanie ludności polskiej po 1944 r. Jej liczba w 1959 r. wynosiła 52,8 tysięcy, co stanowiło 2,8\% populacji radzieckiej Łotwy. Z upływem każdego dziesięciolecia liczba ta malała - aż do 2,3\% (60,4 tys.) w 1989 r. (Eberhardt 1998: 49). Po drugiej wojnie światowej na obszarze obecnej Republiki Łotewskiej osiedliło się także ok. 20 tys. Polaków przybyłych z innych regionów byłego ZSRR, głównie z Białorusi. Prowadzona przez komunistyczne władze rusyfikacja oraz duży procent napływowej ludności spowodowały, że odsetek osób uznających język polski za rodzimy zmalał z 55,3\% w 1959 r. do 32,5\% w 1970 r. i aż do 21,1\% w 1979 r. Jednocześnie wzrastał procent tych, którzy za rodzimy uznawali język rosyjski: w $1970 \mathrm{r}$. było ich 37\%, w 1979 r. już 44,7\% (Jēkabsons 2015: 229-230). Częśćc Polaków zwłaszcza w Rydze i Lipawie uległą także procesowi łotyszyzacji. Rozmieszczenie ludności polskiej niewiele zmieniło się w stosunku do lat przedwojennych. Najwięcej Polaków nadal zamieszkiwało Łatgalię, zwłaszcza w rejonie dyneburskim (ok. 22 tys.). W Dyneburgu ludność polska stanowiła ok. 13,1\% ogółu mieszkańców, w Rydze ok. 1,8\% (1989 r.) (Jēkabsons 1996: 66-68). Większe skupiska Polaków znajdowały się także w Krasławiu i Rēzekne.

Konsekwentnie realizowana przez wszystkie lata przynależności Łotwy do ZSRR rusyfikacja szczególnie mocno uderzyła w pokolenie Polaków urodzone tuż po wojnie. Język rosyjski dominował w życiu publicznym, w urzędach i miejscach pracy. Wyrugowanie języka polskiego z przestrzeni publicznej oraz szkół, przymusowa edukacja w języku rosyjskim - wszystko to wzmacniało tendencje asymilacyjne ludności polskiej z rosyjskojęzyczną. Katastrofalnie spadła liczba Polaków władających językiem polskim. W roku 1989 było ich jedynie 27,1\%, przy 87,9\% władających językiem rosyjskim oraz 37,6\% łotewskim (Jēkabsons 2012: 275). Zgodnie z oficjalnymi danymi za rok 2011'13, osób deklarujących pochodzenie polskie było na Łotwie 45.892, co stanowi 2,2 proc. ludności kraju. Niestety liczba ta zmniejsza się co roku, dla przykładu: w 1989 r. było 60.416, w 2000 r. - 59.505, w 2007 - 54.121 osób. ${ }^{14}$

Miejscem kultywowania polskiej tradycji i publicznego używania narodowego języka był Kościół katolicki. Języka polskiego wciąż jeszcze nauczano w Katolickim Seminarium Duchownym w Rydze, które stało się kuźnią katolickich kadr duchownych dla całego obszaru ZSRR (Byczkowski 1993: 244-245). W seminarium wykładali kapłani o polskich korzeniach, m.in. Leonard Kozłowski- rektor. Także wielu absolwentów uczelni było z pochodzenia Polakami - np. ks. Czesław Wilczyński, ks. Jan Śnieżyński, ks. Józef Kornaszewski15.

Wynarodawiającej polityce nie ulegało w większości starsze pokolenie Polaków, pamiętające lata wolnej Łotwy. Jego przedstawiciele przeciwstawiali się komunistycznej władzy, organizując tajne komplety

13 Dane liczbowe pochodzą z Centralnego Urzędu Statystycznego Łotwy - wg stanu na 1 stycznia 2012 roku (w oparciu o wyniki spisu ludności z 2011 r.).

14 Raport o sytuacji Polonii i Polaków za granica, Ministerstwo Spraw Zagranicznych, Warszawa 2013, s. 150.

15 Spis polskich kapłanów zob. (Szuba 1993: 292). 
służące kultywowaniu kultury i nauczaniu ojczystego języka. Taką działalność od 1945 r. - podobnie jak w czasach niemieckiej okupacji prowadziła nauczycielka i organizatorka polskiego szkolnictwa na Łotwie Julia Ostrowska (Kolbuszewski 1994:45). Prowadził je także Bolesław Gołubiec, przedwojenny pracownik Ambasady RP w Rydze.

Szczególnym miejscem zachowania polskości w radzieckiej Łotwie były tzw. „polskie domy”. „W patriotycznych domach polskich „mówiło się” tylko po polsku i kultywowało się polskie tradycje, zwłaszcza te związane ze świętami kościelnymi, takimi jak Boże Narodzenie czy Wielkanoc. Wnętrza polskich domów także miały swoisty charakter. Ich nieodłącznymi elementami były przedmioty o charakterze religijnym i patriotycznym. Obowiązkowym wyposażeniem „domu polskiego" były (i są obecnie) biblioteczki zawierające polskie książki. ${ }^{16}$ Przy braku innych możliwości kultywowaniu polskości służyło wspólne spędzanie czasu przez znające się polskie rodziny. W latach stalinowskich takie spotkania miały bardziej konspiracyjny charakter. Wraz z następującą odwilżą stały się one bardziej towarzyskie. Rodziny - np. Wesserowie, Głoweccy czy Gołubcowie, Ignatowiczowie, Surdek, Puḳe, Danusewiczowie, Fiskowiczowie i wiele innych - obchodziły polskie święta i rocznice narodowe we wspólnym gronie. Organizowano spotkania towarzyskie o różnorodnej tematyce, np. bal u króla Ćwieczka, karnawałowe bale przebierańców, a także wycieczki po Łotwie, które umożliwiały wspólne spędzanie czasu w polskim środowisku. Według świadków ta swoista forma kultywowania polskości była tolerowana przez władze ${ }^{17}$. Warto też wspomnieć, że dzięki przedstawicielom wspomnianych wyżej rodzin w 1971 r. przy Domu Kultury Nauczycieli w Rydze zaczęły działać kursy języka polskiego pod kierownictwem Bolesława Gołubca, nie były to jednak zwykłe kursy językowe, ale raczej szkoła wychowania patriotycznego oraz nauka poszanowania tradycji i obyczajów polskich ${ }^{18}$.

W końcu lat siedemdziesiątych przedstawicielom polskiej inteligencji, w osobach Wandy Puķe i B. Gołubca, udało się uzyskać zezwolenie na założenie „Klubu Przyjaciół Polski”, funkcjonującego w ramach "Klubu Przyjaźni Polsko-Radzieckiej". Jego pierwsze spotkanie odbyło się 14 kwietnia 1978 r. Przy Klubie został zorganizowany „Zespół Tańca Polskiego Polonez”, następnie również tenże Klub otrzymał nazwę „Polonez”. Instytucja pod nieoficjalnym przewodnictwem B. Gołubca działała do 1988żnorakie przeszkody stwarzane przez władze radzieckiej Łotwy. Wielu członków grupy stało się aktywnymi działaczami społeczności polskiej po odzyskaniu przez Łotwę niepodległości w 1991 r.

16 O pojęciu 'polskiego domu” zob. (Biernat 3003: 141-151).

17 Wywiad M. Michaliszyn z Haliną Glovecką, październik 2016 r. , źródło: archiwum autorki.

${ }^{18}$ D. Malzuba, Trzydzieści lat działalności Klubu Kultury Polskiej „Polonez”, online: http://www.polonia.lv/news.php?lang=2\&cPath=1\&new_id=213 [data dostępu: 10.10.2016.]. 


\section{Działania na rzecz niepodległości republiki}

Polacy brali aktywny udział w przemianach zachodzących na Łotwie na przełomie lat osiemdziesiątych i dziewięćdziesiątych. Opowiadali się po stronie walczących o niepodległość. Uczestniczyli w działaniach Łotewskiego Frontu Narodowego, który był architektem dążeń niepodległościowych. Szczególnie zasłużona dla aktywowania polskiej mniejszości na Łotwie była właśnie pochodząca z rodziny mieszanej (polsko-łotewskiej) Ita Kozakiewicz, która szybko stała się symbolem wspólnej walki Łotyszy i łotewskich Polaków o wolny kraj. Pełniła ona funkcję przewodniczącej Komisji ds. Narodowych, a w 1988 r. wybrana została na członka zarządu Frontu Narodowego Łotwy. W tym samym roku odbył się Kongres Założycielski Asocjacji Towarzystw Kultur Narodowych Łotwy. W najważniejszym, podstawowym dokumencie Asocjacji zostały wpisane deklaracje precyzyjnie sformułowane przez Itę:

Wszystkie mniejszości narodowe będq mogły swobodnie $i$ bez przeszkód rozwijać i uzupetniać swojq własna kulture pod warunkiem, że naród totewski będzie wolnym i petnoprawnym gospodarzem $i$ będzie sam decydowat o wlasnym losie na ziemi, która jest jego etniczna ojczyzna (Melnalksnis 2007: 33).

Dalej Kozakiewicz podkreślała:

Rozwój języka i kultury i rozwój autonomii kulturalnej jest świętym prawem każdej grupy narodowościowej, pod jednym wszakże warunkiem - nie może to się odbywać kosztem rdzennej ludności. My, lotewscy Polacy, żyjemy tutaj od wielu pokoleń i dlatego żadne problemy narodu totewskiego nie sq nam obce ani obojętne (Melnalksnis 2007: 33).

Ita Kozakiewicz zarysowała ramy ideowe działalności mniejszości polskiej oraz pozostałych mniejszości narodowych na Łotwie. Jej stanowisko stało się argumentem $\mathrm{w}$ dyskusji $\mathrm{z}$ mniejszością rosyjską żądającą szczególnych praw w odradzającym się państwie. W marcu 1990 r. Kozakiewicz została wybrana do Najwyższej Rady Łotewskiej SRR, w której objęła stanowisko przewodniczącej Komisji ds. Praw Człowieka i Kwestii Narodowych. Do historii przeszła jej zdecydowana postawa w kwestii deklaracji niepodległości Łotwy. Po zabraniu głosu na posiedzeniu Najwyższej Rady stwierdziła ona bowiem, że deklaracja niepodległości Łotwy jest nie tylko pragnieniem większości wyborców, lecz także historyczną koniecznością, i że powinna ona być przyjęta tu, teraz i w takim ksztatcie, w jakim jest zaproponowana (Melnalksnis 2007: 66-73). W 1990 roku Ita Kozakiewicz została wyróżniona honorowym tytułem KobietaŁotwa. 


\section{Ramy instytucjonalne}

W 1988 r. rozpoczą się renesans łotewskiej Polonii. Latem (8 sierpnia) w Dyneburgu utworzony związek Polaków, który otrzymał nazwę „Promien”. Polskie organizacje powstały także w Rydze, Lipawie, Iłukszcie, Windawie, Rzeżycy, Posiniu, Krasławiu. Nazwa „Promień” nawiązywała do przedwojennego towarzystwa katolickiego o tej samej nazwie. Prezesem został Henryk Świerkowski. W styczniu 1990 r. na ogólnopaństwowym zjeździe, na bazie Towarzystwa Społeczno Kulturalnego Polaków, utworzono Związek Polaków na Łotwie. Jego prezesem została wybrana I. Kozakiewicz. Jeszcze w tym samym roku ZPE posiadał oddziały w Dyneburgu, Iłukszcie, Krasławiu, Rzeżycy, Jełgawie, Kiesiu, Lipawie, Jakubowie, Windawie, Dobele i Jurmali.

W 1990 r. w Rydze reaktywowano także sportowy klub „Reduta”. Po odzyskaniu niepodległości pojawiły się pierwsze media w języku polskim: czasopismo „Polak na Łotwie” (pierwsze wydanie w 1991 r.), późniejsze "Czas Latgalii", "Echo Rygi". W 1990 roku ruszyły też pierwsze audycje radiowe w języku polskim (Byczkowski 1991: 248). Jednocześnie podjęto działania zmierzające do odbudowania polskiego szkolnictwa na Łotwie. Język polski zaczął być nauczany regularnie w polskich klasach przy szkołach łotewskich i rosyjskich oraz w szkołach niedzielnych już w 1988 r. Rok później nastąpiło oficjalne uruchomienie szkolnictwa w języku narodowym dla polskiej mniejszości. W 1991 roku funkcjonowały trzy polskie szkoły: w Rydze, Dyneburgu i Krasławiu, od roku 1994 istniało sześć polskich szkół i jedno przedszkole w Dyneburgu (Ulrińska, Jurzysta 1994: 114,116). Wkrótce reaktywowano polskie harcerstwo, które było jedną z form życia społecznego przyciągającą znaczną część dzieci i młodzieży polskiej (Jēkabsons 1996: 71-72). Jego animatorką była Janina Głowecka, przedwojenna harcerka i drużynowa.

Działania polskiej społeczności aktywnie wspierała restytuowana w 1991 roku po latach polska placówka dyplomatyczna. ${ }^{19}$ Pierwszym składem polskich dyplomatów kierował Jarosław Lindenberg, początkowo jako Chargés d'affaires, później Ambasador RP. Jego współpracownikami byli m.in. Paweł Czerwiński oraz Jarosław Sozański.

Oprócz aktywności wspierających wzmacnianie i rozwój struktur ZPŁ, placówka podjęła działania na rzecz zwrotu majątków potomkom osób, które posiadały majątki ziemskie, głównie na obszarze Łatgalii w przedwojennej Łotwie. Sukcesem odnowionej placówki było także uzyskanie od władz łotewskich zgody na objęcie Polaków, którzy zamieszkiwali przedwojenną Republikę Łotwy i nie będącymi obywatelami (robotnicy sezonowi, mieszkańcy II RP, którzy dali się na terytorium Łotwy po wejściu napaści wojsk niemieckich i później sowieckich na Łotwę oraz Polacy, którzy przybyli na Łotwę z byłych terytoriów RP już w czasach ŁSRR) trybem uprzywilejowanym uzyskiwania obywatelstwa. Dzięki zabiegom

19 Ambasada Polska w Rydze wznawiała działalność po przerwie spowodowanej zerwaniem stosunków dyplomatyczną z Polską przez Łotwę we wrześniu 1939 r. okupacją sowiecką na Łotwie. 
polskich dyplomatów wspomnianych Polaków objęto procedurą uproszczoną przeznaczoną dla obywateli Litwy i Estonii do 1940 r.. Część Polaków mieszkających na Łotwie pragnęła także odzyskać obywatelstwo polskie, które posiadało przed wojną. Tu też pracownicy Ambasady angażowali się aktywnie. Wielką pomocą dla łotewskich Polaków było uzyskanie zgody na zaliczenie stażu emerytalnego nabytego w ŁSRR do uzyskania emerytur w Polsce. Dzięki temu wielu Polaków na Łotwie otrzymywało świadczenia emerytalne w wysokości 200 do 400 dolarów miesięcznie, które de facto pozwalały im przeżyć w trudnych warunkach transformacji ekonomicznej na Łotwie. ${ }^{20}$

\subsection{Związek Polaków na Łotwie- osobowości i działania.}

Budowanie silnego i wpływowego środowiska łotewskich Polaków utrudniło w znacznym stopniu odejście Ity Kozakiewicz, która zmarła tragicznie 28 października $1990 \mathrm{r}$. w drodze powrotnej z pierwszej konferencji Polonii z obszaru byłego ZSRR Kraj-emigracja (por. Melnalksnis 2007: 83). Żegnały ją tysiące obywateli Łotwy, niezależnie od narodowości. Pośmiertnie odznaczono ją Krzyżem Komandorskim z Gwiazdą Orderu Zasługi za wybitne działania na rzecz polskości w Republice Łotwy. Jej imieniem nazwano pierwszą polską szkołę w Rydze. Następcą I. Kozakiewicz na stanowisku Prezesa ZPŁ został Robert Seliszka (Krukowska 1993, 244-245).

Trzecim prezesem ZPŁ została M. Szymańska z domu Tarwid. Jako uznany chemik i członek honorowy Łotewskiej Akademii Nauk była jedną z najwybitniejszych postaci polskiego środowiska. Pani Maria jako młoda dziewczyna podczas wojny działała w strukturach AK na Łotwie, za co została osadzona w Centralnym Więzieniu w Rydze i zesłana do obozu śmierci w Stutthofie. Podczas ewakuacji obozu przez Niemców przeżyła tzw. marsz śmierci - zmuszona, podobnie jak pozostali więźniowie, pokonywać w temperaturze $-20 \mathrm{C}^{\circ}$ po $20-30 \mathrm{~km}$ dziennie. Po wojnie wróciła na Łotwę, podjęła studia. W $1952 \mathrm{r}$. była jedną z trzech pierwszych kobiet, które uzyskały w ŁSRR tytuł doktora. Szefowała Łotewskiemu Stowarzyszeniu Farmaceutów. Za osiągnięcia w nauce została odznaczona trzema medalami naukowymi (Grosvalds, Grinevičs 2012: 61-67). Nigdy nie wstąpiła do Komunistycznej Partii Łotwy, była także człowiekiem głęboko wierzącym. Jako redaktor naczelny współtworzyła pismo „Polak na Łotwie”. Zmarła 10 lipca $1995 \mathrm{r}$.

Wybitnym działaczem ZPŁ był Michał Bartuszewicz. Podobnie jak M. Szymańska podczas wojny był uczestnikiem ruchu oporu w strukturach Armii Krajowej, za co osadzono go w obozie Stutthof. Bohaterska ucieczka uratowała go przed tragicznym zakończeniem życia w „marszu śmierci”,

20 Wywiad z Ambasadorem RP w Słowenii Pawłem Czerwińskim, w latach w latach 1991-1996 pełniącym funkcję II sekretarza Ambasady RP w Rydze. Lipiec 2018, źródło: archiwum autorki. 
który to los spotkał wielu jego współwięźniów. Został jednak ujęty przez sowiecki kontrwywiad wojskowy, długo przesłuchiwany i w końcu wcielony do Armii Czerwonej. Podczas walk nad Odrą został ciężko ranny²1. M. Bartuszewicz pełnił funkcję prezesa Ryskiego Oddziału ZPŁ, reprezentował także sprawy Polaków w Asocjacji Mniejszości Narodowych Łotwy. „Pan Michał”, jak kordialnie określano go w polskim środowisku, szczególnie zasłużył się dla mediów polonijnych na Łotwie - przez kilka lat tworzył audycje polskie w Radiu Łotewskim. Był także twórcą, wieloletnim redaktorem naczelnym i redaktorem honorowym periodyku „Polak na Łotwie”. Zmarł w 2010 r. wieku 95 lat.

Wieloletnim (2000-2012) i zasłużonym prezesem ZPŁ była Wanda Krukowska. Najważniejszym osiągnięciem ZPŁ za jej kadencji stał się według jej własnej oceny - rozwój życia kulturalnego łotewskich Polaków. Pani prezes zainicjowała wydarzenia, które na trwałe wpisały się do kalendarza miejscowej Polonii, m.in. Festiwal Kolęd w Krasławiu (obecnie także w Rzeżycy). Podczas jej prezesury tradycją stał się Festiwal Kultury Polskiej w Posiniu, którego pomysłodawcą był prezes Oddziału ZPŁ w Posiniu Edward Dukszta. Festiwal w 2016 r. został zorganizowany już po raz dwudziesty. Święto polskich tradycji rozpoczyna Msza św. w zabytkowym (z roku 1761) kościele pw. św. Dominika w Posiniu, sprawowana niejednokrotnie przez życzliwego wobec polskich inicjatyw biskupa Archidiecezji Agłońskiej Jānisa Bulisa. Centralnym punktem programu jest koncert galowy polskich chórów i zespołów, głównie z Dyneburga, Krasławia, Rzeżycy i Jakubowa ${ }^{22}$. W. Krukowska zmarła 15 stycznia 2018 r. W 2012 r. na prezesa Związku wybrano cenionego w polskiej społeczności Ryszarda Stankiewicza, który wcześniej (także obecnie) pełnił funkcję prezesa Dyneburskiego Oddziału ZPŁ. W 2016 r. R. Stankiewicz ponownie został wybrany prezesem ZPŁ na kolejną kadencję. Do niewątpliwych zasług prezesa Stankiewicza należy kontynuowanie, pomimo trudności finansowych w latach 2011-2014 (Kalczyńska 2014: 42), wydawania kolejnych numerów „Polaka na Łotwie” oraz realizowania programu telewizyjnego Polskie Akcenty. Do najważniejszych zadań Oddziału Głównego ZPŁ należy koordynacja działalności regionalnych oddziałów, reprezentowanie łotewskich Polaków na zjazdach polonijnych poza Łotwą, inicjowanie i organizowanie wydarzeń mających na celu zachowanie polskiego dziedzictwa narodowego. ZPŁ kontynuuje wydawanie czasopisma w języku polskim „Polak na Łotwie” (Krukowska 1993: 306).

Przez szereg lat funkcję redaktora naczelnego tego periodyku pełnił Romuald Lebedek - dziennikarz i tłumacz i były wiceprezes ZPE. Pismo współtworzyła także Irēna Hemane, emerytowana nauczycielka szkoły polskiej. Obecnie czasopismo tworzą: redaktor naczelny R. Stankiewicz oraz redaktorzy: Krystyna Kunicka i Stanisław Januszkiewicz. Prace wspierają

${ }^{21}$ R. Lebedek, Żegnaj Panie Michale, [w:] Polak na Eotwie, $\mathrm{nr} 1$ (87) 2009; http://www.polak.lv/87/redakcja.shtml. [data dostępu: 05.10.2017.]

${ }^{22}$ R. Stankiewicz, XVIII Festiwal Kultury Polskiej $w$ Posiniu, online: http://www.polonia.lv/news.php?lang=2\&cPath=7\&new_id=198 [data dostępu: 05.10.2016]. 


\section{Monika Michaliszyn: Mniejszość polska w odrodzonej Łotwie}

łotewscy i polscy specjaliści, m.in. E. Jēkabsons, J. Radziņa, B. Chmielewski, B. Mikołajczyk, M. Głuszko, M. Michaliszyn, T. Otocki i inni. Coraz aktywniej w tworzeniu pisma uczestniczy młode pokolenie łotewskich Polaków, wśród których szczególną aktywnością wyróżnia się wspomniana K. Kunicka.

Oddziałem Ryskim ZPŁ przez wiele lat kierowała zasłużona działaczka łotewskiej Polonii i wieloletnia dyrektor Polska Średnia Szkoły Ogólnokształcącej im. Ity Kozakiewicz w Rydze - Maria Puzyna Fomin, zmarła 5 grudnia 2015 r. Największe zasługą dla polskiego środowiska już nie tylko w Rydze, ale i całej Łotwie było wieloletnie kierowanie przez nią wspomnianą szkołą polską im. Ity Kozakiewicz w Rydze od początków jej założenia w 1991. M. Fomin, jak wspominała inna zasłużona dla Polonii łotewskiej działaczka - Irēna Platace, została nominowana na dyrektora szkoły jeszcze przez I. Kozakiewicz. Wybór ten, jak twierdzi I. Platace, był opatrznościowy. Nikt inny bowiem „(..) nie podołałby tym wszystkim

wyzwaniom: znaleźć nauczycieli, dzieci, budynek, przejść przez wszystkie biurokratyczne bariery takie jak np. pierwsza akredytacja szkoły (...) ${ }^{23}$ ”. Obecnie szkołą polską w Rydze kieruje były wykładowca języka i kultury polskiej w Łotewskiej Akademii Kultury Krzysztof Szyrszeń

Prezesami ZPŁ w Rydze byli także Irēna Strautmale oraz Adam Kropiwiec. Od 2016 r. funkcję prezesa ZPŁ w Rydze pełni Andžella Liepa (pełniąca także funkcję wicedyrektora wspomnianej wyżej szkoły polskiej w Rydze). Głównym celem nowej szefowej jest zintegrowanie ryskich Polaków bez względu na wiek i zainteresowania. Służyć temu mają projekty umożliwiające kontakty międzyludzkie - konkursy (np. na najsmaczniejszą szarlotkę) i imprezy integracyjne, takie jak wspólne spotkania przy kręglach ${ }^{24}$. Podczas tzw. bowlingu frekwencja bywa tak duża, że rywalizuje ze sobą aż 11 drużyn!25 Integracji ryskiej Polonii służyć ma też nowo założona strona internetowa ${ }^{26}$ oraz prowadzony przez wiceprezes ZPŁ w Rydze I. Strautmale Biuletyn Informacyjny (w wersji internetowej oraz papierowej).

Centrum działalności Ryskiego Oddziału ZPŁ stała się wspomniana Polska Średnia Szkoła Ogólnokształcąca im. Ity Kozakiewicz w Rydze, mieszcząca się przy ul. Nicgales $15^{27}$. W Rydze istnieje Klub Kultury Polskiej „Polonez”, którego wieloletnim prezesem był zmarły w 2016 r. Edward Fiskowicz - wybitny animator kultury polskiej na Łotwie. Urodzony w 1923 r. w Rzeżycy w latach 3otych uczęszczał do polskiej szkoły powszechnej oraz do Państwowego Gimnazjum Polskiego w Rzeżycy. Kształcił się w szkole muzycznej, którą zamknięto w 1939 r. Od 1937 r. występował w przedstawieniach teatralnych, organizował teatr lalkowy $\mathrm{w}$ rodzinnym

23 T. Otocki, Ostatnie pożegnanie dyrektor szkoły polskiej w Rydze, http://zw.lt/swiat/ostatniepozegnanie-dyrektor-polskiej-szkoly-w-rydze/[data dostępu: 08.10.2017.]

24 Wywiad M. Michaliszyn z Prezes Ryskiego Oddziału ZPŁ A. Liepą, listopad 2016, źródło: archiwum autorki.

25 „Bowling” - wspólna zabawa, online: http://ryga.zpl.lv/bowling-wspolna-zabawa-2016/ [data dostępu: 08.10.2017].

${ }^{26} \mathrm{http}: / /$ ryga.zpl.lv/o-nas/ryski-oddzial-zpl/ [data dostępu: 17.10.2016.]

27 I. Strautmale, Biuletyn Informacyjny $n r$ 1, online: http://ryga.zpl.lv/biuletyn-informacyjny-nr-12016/ [data dostępu: 08.10.2016]. 
mieście. W czasie okupacji niemieckiej zaangażował się w kolportaż ulotek Armii Krajowej. W 1943 r., po aresztowaniu, pracował przy obsłudze wojska niemieckiego w Rydze, skąd udało mu się uciec w październiku 1944 r. Ukrywał się do maja 1945 r., po czym został zesłany na Syberię. W latach 1945- 1948 pracował $\mathrm{w}$ syberyjskim lagrze, gdzie za zezwoleniem komendanta, organizował i prowadził orkiestrę łagrową "Simfo - Džaz"28. Po powrocie na Łotwę, zamieszkał w Rydze i zajął się pracą artystyczną. Występował w teatrze, był dyrygentem, prowadził żeński zespół muzyczny, koncertował. Od 1978 r. czynnie uczestniczył w życiu Klubu Kultury Polskiej "Polonez", którego był także prezesem ${ }^{29}$. W 1983 r. pod jego kierownictwem został utworzony chór o tej samej nazwie, działający prężnie do dzisiejszego dnia. Organizował wiele imprez kulturalnych, głównie literackomuzycznych, m.in. Konkurs Polskiej Piosenki Estradowej (wspólnie z ZAKR), przedstawienia w placówkach Oddziałów ZPŁ ${ }^{30}$. Przyjmując Krzyż Kawalerski Orderu Zasługi Rzeczypospolitej Polskiej pan Edward w podziękowaniu zaśpiewał patriotyczną pieśń polską Ptynie Wisła, płynie, dodając jednak zwrotkę własnego autorstwa: U nas tė̇, na Łotwie, piękna Dźwina ptynie, piękna Dźwina, płynie / A na brzegach Dźwiny polskość tu nie ginie, polskość tu nie ginie... ${ }^{31}$.

„Polonezowi” szefowali także Edīte Dmuchowska- Grava oraz Jan Wiśniewski. Obecnie prezesem klubu jest Dagmara Malzuba.

Pod auspicjami Ryskiego Oddziału ZPE, z inicjatywy Haliny Głoweckiej oraz Ireny Liǵeniece, w 2008 r. powstał Klub Słowa Polskiego „Gawęda”, w ramach którego odbywają się spotkania osób zainteresowanych kulturą i językiem polskim.

W 1995 r. w Rydze powstała Liga Polskich Kobiet na Łotwie, kontynuująca tradycje Polskiego Towarzystwa Dobroczynności, działającego w Rydze od 1878 do 1940 r. ${ }^{22}$ Jej podstawowym celem jest pomoc charytatywna osobom polskiego pochodzenia, głównie starszym i chorym. Założycielką organizacji była Džuljetta Lange. Od 1998 do 2009 r. funkcję prezesa Ligi pełniła Inga Plocina. Obecnie obowiązki prezesa sprawuje Maria Legeza. Działaczki LPK prowadziły kursy języka polskiego, organizowały wieczorki polskiej kultury, a także opiekowały się osobami

\footnotetext{
28 J. Gribule, Edward Fiskowicz - in memoriam [w:] Akant; http://akant.org/archiwum/184-swiatinflant/swiat-inflant-2017/swiat-inflant-2017-nr-2/5774-jolanta-gribule-edward-fiskowicz-inmemoriam (data dostępu: 04.03.2018)

29 Edward Fiskowicz, Polacy na Wschodzie [w:] Archiwum pamięci mówionej, http://www.audiohistoria.pl/web/index.php/swiadkowie/osoba/id/2477/from/szuk , [12.07.2017]. ${ }^{30}$ Za zasługi dla krzewienia polskości na Łotwie Prezydent RP Lech Kaczyński uhonorował Krzyżem Kawalerskim Orderu Zasługi Rzeczypospolitej Polskiej także żonę E. Fiskowicza Walerię Fiskowicz, por. R. Lebedek, Prezydent Polski gościem Polonii łotewskiej, „Polak na Łotwie” 2007, nr 2, http://www.polak.lv/80/wizyta.shtml. [data dostępu: 12.10.2016].

${ }^{31}$ Ambasada RP w Rydze, Odznaczenie dla Pana Edwarda Fiskowicza, online : https://www.youtube.com/watch?v=-JpZl6lfvaQ [data dostępu: 12.10.2016].

${ }^{2}$ Ambasada RP w Rydze, Jubileusz Klubu Kultury Polskiej „Polonez” w Rydze, online:

https://www.msz.gov.pl/pl/p/ryga_lv_a_pl1/aktualnosci/jubileusz_klubu_kultury_polskiej_pol onez_w_rydze;jsessionid=DC6725A9Fo4B5B3AF2FEF682B044D25D.cmsap2p?printMode=true [data dostępu: 22.10.2016].
} 
starszymi i niepełnosprawnymi. Na liście osób pozostających pod opieką Ligi Polskich Kobiet jest ponad 60 nazwisk33.

W działalności polonijnej największą aktywność wykazywał Dyneburski Oddział ZPŁ „Promień”. Obecnie jego prezesem jest wspominany już R. Stankiewicz. Z racji dużej liczebności Polaków Dyneburg to jedyne miasto na Łotwie, gdzie istnieje Dom Polski, zwrócony organizacji polskiej przez władze łotewskie po odzyskaniu przez kraj niepodległości. Dom znajduje się przy ul. Warszawskiej 30. Bardzo prężnie działającą placówką w największym mieście Łatgalii jest Centrum Kultury Polskiej z otwartą w 2006 r. Galerią Artystyczną Domu Polskiego (Herman, 2009: 153). CKP powstało w 1997 r. z inicjatywy dyneburskich Polaków i władz miasta. Jest to instytucja mająca popularyzować wiedzę o kulturze i historii Polski, co realizuje poprzez organizowanie imprez kulturalnych, licznych wystaw polskich i łotewskich artystów (także absolwentów szkoły polskiej w Dyneburgu), konkursów, festiwali, m.in. pieśni patriotycznej i innych. Aktywność Centrum możliwa jest dzięki obecności różnorakich zespołów i kółek zainteresowań dla dzieci i dorosłych, takich jak działający już około 30 lat chór „Promien” prowadzony przez Gertrudę Kiewicz, obecnie zaś Reginę Krukowską. Przy CKP działa też cieszący się międzynarodowym uznaniem młodzieżowy zespół tańca ludowego „Kukułeczka”, którego dyrektorem artystycznym jest Żanna Stankiewicz ${ }^{34}$, pełniąca jednocześnie funkcję dyrektora CKP w Dyneburgu (Herman, 2009: 155). Zespół w 2006 r. został laureatem nagrody Telewizji Polonia „Za sławienie Polski i polskości”. Zainteresowania muzyczne młodzi ludzie mogą rozwijać także w grupie wokalnej „Barwy Daugawy”. W Domu Polskim działają grupy teatralne „Twórczy Pryzmat” oraz „Uśmiechnięta Tęcza”, kierowane przez Milenę Różańską. Funkcjonuje też Uniwersytet Trzeciego Wieku, a najmłodsi uczniowie szkoły uczestniczą w działalności „Klubu Twórczego Rozwoju Dziecka Polska Chatka”. Starsza młodzież aktywnie udziela się w Klubie Stypendystów „Semper Polonia”, skupiającym studentów uczelni dyneburskich. Członkowie klubu nie tylko wspóltworzą życie kulturalne CKP, ale też dbają o zachowanie polskiego dziedzictwa narodowego w Łatgalii i opiekują się grobami poległych legionistów polskich. Biorą także udział w projektach międzynarodowych. Ponadto przy Centrum Kultury funkcjonują kierowane przez Wandę Hryniewicz Klub Seniorów i Biblioteka „Promien” oraz oddział dyneburski Klubu Polskich Kobiet, zarządzany przez Wilhelminę Kokinę. Organizowane są także spotkania dla katolików. Co roku dyneburscy Polacy maszerują w barwnym korowodzie, świętując Dzień Polonii i Polaków za Granicą, dzień Konstytucji 3 maja oraz Święto Ulicy Warszawskiej. W te dni odbywa się też festiwal „Polski Folklor w Łatgalii” (Kalczyńska 2013: 425).

"Polski dom" bierze udział w organizacji różnych tradycyjnych i narodowych świąt (święto Konstytucji 3 Maja, Święto Niepodległości),

33 Wywiad M. Michaliszyn z byłą prezes Ligi Polskich Kobiet Ingą Pḷociṇą, Ryga 2014.

34 Prywatnie żona prezesa ZPŁ R. Stankiewicza. 
zwłaszcza w Międzynarodowego Festiwalu Polskiej Młodzieżowej Piosenki Religijnej35.

Jedną z aktywniejszych Polek w Łatgalii jest Halina Szakiel, założycielka Towarzystwa „Inflanty” w Dyneburgu, opiekującego się polskimi grobami w Inflantach, m.in. przedwojennych działaczy polskich Jana Wierzbickiego i ks. Bolesława Ławrynowicza36. H. Szakiel jest także kustoszem pamięci inflanckich Polaków. Dzięki jej zbiorom powstała prezentowana w Polsce wystawa zatytułowana Polacy $w$ Inflantach. Pamięć i tożsamość, stworzona przez jej syna Ludwika Szakiela37.

Także w Rydze istnieje odwołujące się do danej nazwy ziem łotewskich przynależących ówcześnie do Polski: Towarzystwo „Inflanty”. Kierowane przez Jana Hryniewicza (łot. Ivans Grin̄ēvičs) stawia sobie za cel poszerzanie wiedzy historycznej na temat wspólnej historii Polski i Łotwy. Szef Towarzystwa „Inflanty” wraz z wybitnym łotewskim profesorem Ilgvarsem Grosvaldsem jest autorem cennych publikacji na temat relacji polsko-łotewskich.

Aktywność kulturalną prowadzą również polskie chóry i zespoły muzyczne, które działają w Rydze (Polonez, Wisła), w Dyneburgu („Promień), w Rzeżycy („Jutrzenka”), w Krasławie („Strumień”), w Lipawie („Bursztynki”), w Jełgawie („Stokrotki”). Polonijne chóry co roku organizują „Festiwal Kolęd Polskich”, odbywający się w kościele św. Ludwika w Krasławiu. W Rydze istnieją także młodzieżowe zespoły taneczne. Jednym z nich jest „Daugaviņa” (kierowana przez E. Dmuhovską- Gravę, która działa przy łotewskiej "Ryskiej Szkole Średniej Hanza" (Rīgas Hanzas viduskola). Do zespołu tego należą głównie Łotysze, którzy chcą poznać polską kulturę i tradycje tańca ludowego. Na konkursach międzynarodowych występują oni w narodowych strojach ludowych, uszytych własnoręcznie przez kierowniczkę „Daugaviņa”. Szkoła "Hanza" organizuje także wymianę uczniów ze szkołami średnimi w Polsce ${ }^{38}$.

$\mathrm{Na}$ Łotwie funkcjonują również media polonijne. Oprócz wspomnianego już „Polaka na Łotwie” w Dyneburgu wydawane było „Słowo Polskie”. W języku polskim wydawany był także „Nasz Czas”. Od ponad 25 lat na falach IV Programu Radia Łotewskiego cyklicznie nadawany jest 30minutowy program radiowy Nasz Gtos (obecnie w każdy pierwszy

35 Por. Latvijas poḷ nevalstisko organizāciju ilgtermina sadarbības modelis, Par materiāla saturu atbild biedrība „Latvijas Poḷu biedrība POLONEZ”,

http://www.sif.gov.lv/nodevumi/nodevumi/5148/SM_Polu\%2oNVO_last.pdf, [data dostępu:

28.06.2017]

36 Tamże, s. 433.

37 Polacy $w$ Inflantach. Pamięć i tożsamość, online: http://mob.starogard.pl/194-starogardgdanskipolacy-w-inflantach-pamiec-i-tozsamosc [data dostępu: 22.10.2016]. Por. także M. Kalczyńska, Z historii i współczesności Polaków) w wielokulturowym Dyneburgu, w krainie Łatgalii (Kalczyńśka 2012: 393)

https://books.google.pl/books?id=Df98wpm8I_cC\&pg=PA393\&lpg=PA393\&dq=hALINA+SZAKIE L\&source $=$ bl\&ots $=$ JJvVUmsAG6\&sig $=710$ VfKOHPlLvfcG-

NJkeHyMiS4k\&hl=lv\&sa=X\&ved=oahUKEwjC7rqlhI3cAhXFFSwKHRdeAvUQ6AEITTAJ\#v=onep age\&q=hALINA\%20SZAKIEL\&f=false [data dostępu: 06.07.2018)

38 Inicjatorem współpracy między szkołami- Ryską Szkołą Średnią Hanza a III Liceum im. Gen. Sowińskiego w Warszawie-była autorka niniejszego artykułu. 


\section{Monika Michaliszyn: Mniejszość polska w odrodzonej Łotwie}

poniedziałek miesiąca o godz. 19.16 czasu łotewskiego). Polską audycję tworzy I. Liǵeniece, która w 2006 otrzymała Grand Prix Polonijnego Festiwalu Multimedialnego „Polskie Ojczyzny 2006”. Od 2008 roku w przygotowaniu programu uczestniczy także jej córka- Liene Liǵgeniece, która opracowuje audycje od strony dźwiękowej.

Również w Dyneburgu emitowane są programy radiowe w języku polskim, istniejący niegdyś „Głos Młodych Polaków” zastąpiła „Polskofalówka”. W telewizji kablowej w tym mieście regularnie prowadzona jest wspomniana polska audycja „Akcenty Polskie”, której można posłuchać także w Internecie39. Na terenie całej Łotwy można odbierać TV Polonia, kierowaną specjalnie do rodaków mieszkających poza granicami RP. Dużą popularnością cieszy się także odbierana w systemie satelitarnym Telewizja „Trwam”. Na falach krótkich jeszcze w latach dziewięćdziesiątych odbierać można było „Radio Maryja”. Teraz odbierano jest ono poprzez lącza internetowe lub też satelitarne.

Aktywnie działają także Oddziały ZPŁ w mniejszych miejscowościach - Jełgawie, Rzeżycy, Lipawie, Jakubowie.

22 stycznia 1998 r. powstał Związek Młodych Polaków na Łotwie. Powołano go z myślą o zjednoczeniu młodych ludzi pochodzenia polskiego i tych, którzy interesują się polską kulturą, językiem i współczesną polską rzeczywistością. Inicjatorami powstania organizacji byli: Ambasada Rzeczypospolitej Polskiej w Rydze, pierwsza prezes ZMPŁ Anna Osite oraz prezes Młodzieżowego Oddziału Związku Polaków na Łotwie - Ryta Semionowa ${ }^{40}$. W następnych latach Związkiem kierowały studentki polskiej specjalizacji w Łotewskiej Akademii Kultury w Rydze: Arina Bogdzeviča (lata: 1999, 2000) oraz Anna Polovka (lata: 2003, 2004), których działalność przyczyniła się do popularyzacji stowarzyszenia wśród młodzieży polskiej, a także nawiązania ścisłej współpracy z Polską oraz sąsiednimi krajami (zwłaszcza Litwą). ZMPŁ we współpracy z Ambasadą RP w Rydze organizował także różnorakie imprezy integracyjne, m.in. bale przebierańców, dyskoteki, wyjazdy studyjne, np. zorganizowana przed wstąpieniem Łotwy do Sojuszu Transatlantyckiego impreza integracyjna Mtodzież Polska na Łotwie popiera wstapienie Łotwy do NATO (Bogdzeviča, 1999: 23-24). Działania organizacji w początkowych latach 1998-2003 aktywnie wspierała M. Michaliszyn, ówczesny wykładowca polskiej specjalizacji ŁAK. Funkcję prezesa ZMPŁ pełniły: Antonina Sudnik (2002), Anna Pitaško (2005), Kristine Morževska, która była również redaktorem działu młodzieżowego $\mathrm{w}$ organie prasowym ZPŁ „Polak na Łotwie”. Jej aktywność koncentrowała się na tworzeniu i udziale ZMPŁ w międzynarodowych projektach, mających na celu kultywowanie polskiego dziedzictwa narodowego. Przez kilka lat prezesem była też Viktorija Mirzajeva. Pod jej kierownictwem działalność Związku polegała na organizacji młodzieżowych wydarzeń kulturalnych (wspólne Wigilie),

39 http://www.grani.lv/tags/akcenty+polskie/ [data dostępu: 06.07.2017)].

$4^{\circ}$ Historia Powstania Związku Młodych Polaków na Łotwie - online: http://www.polonia.lv/index.php?lang=2\&cPath=1|3\&txt_id=2 [data dostępu: 29.10 2016]. 
wycieczek po Łotwie (także po Polsce i Litwie), imprez sportowych41. Obecnym Prezesem ZMPŁ jest Veronika Rahmanova.

Członkowie ZMPŁ uczestniczą w międzynarodowych projektach mających na celu integrację z Polonią z innych krajów, a także biorą udział w letnich kursach w Polsce, reprezentują Łotwę na sportowych imprezach polonijnych.

Łotewscy Polacy zajmują wysokie stanowiska w strukturach administracyjnych i rządowych Łotwy. Polskie pochodzenie ma były szef łotewskiego MSZ - Jānis Jurkāns. Polskie korzenie mają m.in. Vanda Bērziņa- były Główny Specjalista ds. Podatków w Państwowej Służbie Dochodowej, Vita Jermoloviča - Członek Zarządu Ryskiego Biura Rozwoju Turystyki, Alīna Gržibovska- Dyrektor Departamentu Spraw Zagranicznych Uniwersytetu Łotwy, Alfrēds Platacis, były pracownik Urzędu Statystycznego RŁ, uhonorowany za wykonywaną pracę dyplomem uznania Republiki Łotwy. Wybitnym łotewskim Polakiem jest także Rišards Labanovskis- polityk, dziennikarz orz tłumacz polskiej literatury (m.in. dzieł F. Ossendowskiego) na język łotewski.

W 2010 Arcybiskupem Rygi i zwierzchnikiem Kościoła katolickiego na Łotwie został łotewski Polak Zbigṇevs Stankevičs, który przed wstąpieniem na drogę kapłaństwa sprawował funkcję wiceprezesa ZPŁ. W konsekracji Arcybiskupa brał udział Prymas Polski Arcybiskup Józef Kowalczyk. W czerwcu 2018 roku ,za wybitne zasługi dla polskiego Kościoła na Wschodzie, za krzewienie polskiej kultury i tradycji narodowych, za działalność na rzecz polskich mniejszości narodowych. Arcybiskup Stankevičs w czerwcu 2018 r. został odznaczony przez Prezydenta A. Dudę Krzyżem Kawalerskim Orderu Zasługi Rzeczypospolitej Polskiej.42 $\mathrm{Na}$ Łotwie posługę duchowną sprawowało i sprawuje wielu księży z Polski, także władających językiem łotewskim, między innymi ojcowie karmelici- Jarosław Nędza, Zdzisław Maksymilian Podwika, paulini- o. Stanisław Hodun, o. Sywan Marcin Wirkowski, o. Andrzej Stokłosa, jezuici- o. Tadeusz Cieślak, werbiści- o. Tomasz Dudziuk, kapucyni- o. Bronisław Nędza, Witold Wśniewski, ks. Marcin Woźniak, ks. Karol Buziewicz, ks. Andrzej Stokłosa, ks. Edward Woroniecki. Na Łotwie posługują także polskie siostry zakonne. Swoją misję wykonują z duża ofiarnością.

Kontakty między Polską a Łotwą rozwijają się także w dziedzinie turystyki. Współpracę na tym polu rozwijało od roku 1996 Polskie Centrum Informacji, założone i prowadzone przez łotewską Polkę Irēnę Platace. Oprócz zapewnienia wymiany turystycznej między oboma krajami, I.

41 Wywiad z M .Michaliszyn z W. Mirzajewą, źróło: archiwum autorki.

42 Podczas oficjalnej wizyty w dniu 28 czerwca Prezydent RP A. Duda uhonorował wysokimi odznaczeniami państwowymi, m.in. Walentynę Szydłowską (twórczynię i wieloletnią dyrektor Gimnazjum Polskiego w Rzeżycy), I. Liğeniecę, Ž. Stankeviča, R. Stankevičs, K. Kunicka, W. Woroniecki, A. Liepa. i in. O tym zob. Odznaczenia dla zastużonych przedstawicieli polskiej spoteczności na $\quad$ Eotwie. $\quad \mathrm{http} / / /$ www.prezydent.pl/aktualnosci/ordery-iodznaczenia/art,284,zasluzonychprzedstawicieli-spolecznosci-polskiej-na-lotwie.html data dostępu: 06.07.2018). 
Platace organizowała wiele misji biznesowych i turystycznych w Polsce i na Łotwie. Reprezentowała Łotwę podczas pierwszej prezentacji Łotwy na Międzynarodowych Targach Poznańskich oraz imprezach polonijnych w wielu krajach świata43.

\section{Résumé}

Łotewscy Polacy stanowią społeczność dobrze ocenianą przez łotewskie władze, która niejednokrotnie stawiana jako wzór integracji mniejszości narodowej. Jednocześnie je przedstawiciele podejmują wiele inicjatyw w celu kultywowania polskich tradycji narodowych i zachowania polskiego dziedzictwa narodowego i kulturowego. Realizację tych przedsięwzięć ułatwia założona u progu odzyskania niepodległości przez Łotwę organizacja polonijna Związek Polaków na Łotwie. Wiele Celów ZPŁ zostało realizowanych dzięki obecności w niej wybitnych osobowości, takich jak I. Kozakiewicz, M. Szymańska, M. Bartuszewicz i in. Polską społeczność scala także przynależność do Kościoła katolickiego, którego obrzędy tradycje aktywnie kultywują.

Do głównych problemów ZPŁ należą natomiast nadmierna regionalizacja oraz zbyt mała wymiana informacji między poszczególnymi oddziałami działającymi w różnych miastach Łotwy. Dużym problemem jest także zbyt mała liczebność oraz aktywność młodzieży w strukturach Związku Polaków na Łotwie. 44

43 Zob. http: http://www.polinfo.lv/ (data dostępu: 12.06.2017).

44 Por. Latvijas poḷu nevalstisko organizāciju ilgtermiṇa sadarbības modelis, Par materiāla saturu atbild biedrība „Latvijas Poḷu biedrība POLONEZ”,

http://www.sif.gov.lv/nodevumi/nodevumi/5148/SM_Polu\%20NVO_last.pdf, (data dostępu: 28.06.2017). 


\section{Bibiografia}

Albin, J. 1993. Polski ruch narodowy na Łotwie w latach 1919-1940. Wrocław: Wydawnictwo Uniwersytetu Wrocławskiego.

Biernat, T. 2003. Być Polakiem na Łotwie: świat życia codziennego. Toruń: Wydawnictwo Adam Marszałek s. 141-151.

Bogdzeviča, A. Majówka Związku Młodzieży Polskiej. [w:] „Polak na Łotwie” 1999, nr 3, s. 23-24.

Byczkowski, J. 1991. Polacy na Eotwie w latach 1939-199o. [w:] Polacy na Eotwie. Lublin: Wydawnictwo KUL s. 248.

Byczkowski, J. Polacy na Łotwie w latach 1939-199o, [w:] Polacy na Łotwie. red. E. Walewander. Lublin: Wydawnictwo KUL 1993 s. 244-245.

Durejko, A. 2001. Polskie życie kulturalne i literackie w XX w., Wrocław: Sudety.

Durejko, A. 1994. Polskie wiersze nad Dźwiną. Wrocław: Wydawnictwo Uniwersytetu Wrocławskiego.

Dybaś, B. 2004. Na obrzeżach Rzeczypospolitej. Sejmik piltyński w latach 16171717. Toruń: Wydawnictwo Naukowe Uniwersytetu Mikołaja Kopernika.

Eberhardt, P. 1998. Problematyka narodowościowa Łotwy. Warszawa: IGiPZ. PAN s. 49.

Grinevich, I. Grosvalds, I. Arhitektūras vēsturnieks un tēlnieks Konstantīns Rončevskis (1875-1935). „Scientific Journal of Riga Technical University” 2011, $\mathrm{nr} 18, \mathrm{~s} . .$.

Grosvalds, I. Grinevičs, I. Latvijas Zinātṇu akadēmijas goda locekle Marija Šiman,ska, „Scientific Journal of Riga Technical University” 2012, nr 19, ss. 6167.

Herman, A. 2009. Polsko- łatgalska kultura w Dyneburgu, [w:] Polacy nad Dźwina. red. J. Kurczewski, M. Fuszara, Warszawa: Wydawnictwo Uniwersytetu Warszawskiego s. 153.

Janicki, A. 2012. Kurlandia $w$ latach 1795-1915. Gdańsk: Wydawnictwo Uniwersytetu Gdańskiego.

Janicki, A., Jekabsons, E., Laszczkowski M. 2012. Polentechnikum. Warszawa:

Ministerstwo Kultury i Dziedzictwa Narodowego.

Jēkabsons, Ē. 1996. Poḷi Latvijā. Rīga: Latvijas Zinātņu akadēmijas Filozofijas un sociologijas institūtas s. 71-72.

Jēkabsons, E. Polska mniejszość narodowa i kultura polska w historii Łotwy perspektywa wspótczesna. [w:] Na pograniczach literatury. red. J. Fazan, K. Zajas. Kraków: Towarzystwo Autorów i Wydawców Prac Naukowych Universitas 2012, s. 275.

Jēkabsons, $\bar{E}$. Polska mniejszość narodowa na Łotwie i kultura polska $w$ historii Łotwy, [w:] Ludzie, wladza, narody, religie. Lubelszczyzna, Polska, Europa. red. A. Kidzińska-Król. Lublin: Wydawnictwo Uniwersytetu Marii CurieSkłodowskiej 2015, s. 229-230.

Kalczyńska, M. Polacy w Dyneburgu. Historia i wspótczesność - zarys problemu. [w:] Stan badań nad wielokulturowym dziedzictwem Rzeczpospolitej. t. 6. red. W. Walczak, K. Łopatecki. Białystok: Instytut Badań nad Dziedzictwem Kulturowym Europy 2013 s. 425.

Kalczyńska, M. Wybrane funkcje mediów polskich za granica, [w:] Łódzkie Studia Teologiczne, Nr 23, 2014 s. 42.

Kolbuszewski, J. 1992. Polacy na Łotwie. Historia i współczesność. Zarys problematyki. w: H. Kubiak (Ed.) Mniejszości polskie i Polonia w ZSRR. Wrocław: Zakład Narodowy im. Ossolinskich pp. 331. 


\section{Monika Michaliszyn: Mniejszość polska w odrodzonej Łotwie}

Kolbuszewski, J. Kultura Polska na Łotwie. Przeszłość i teraźniejszość. Próba zarysu całości. [w:] Polacy na Łotwie. red. J. Sozański, R. Szklennik, Ryga: Wydawnictwo Ambasada Rzeczypospolitej Polskiej_1994.

Krukowska, W. Działalność Związku Polaków na Łotwie. [w:] Polacy na Łotwie. Lublin: Wydawnictwo KUL s. 244-245.

Kultura polska na Łotwie, red. J. Sozański, R. Szklennik. 1994. Ryga: Wydawnictwo Ambasada Rzeczypospolitej Polskiej.

Kurczewski, J., Volkovs, V. 2012. The Latvians, Russians and Poles of Present Day Daugavpils. Rīga: Zinātne.

Laszczkowski, M. 2013. Welecja. Dzieje korporacji. Warszawa: Towarzystwo Tradycji Akademickiej.

Łotwa pod własna flaga. red. W. Siwiński. Warszawa: PAP 1990, s. 66-73; 77.

Melnalksnis, A. 2007. Godzina dla gwiazdy: Ita Kozakiewicz (1955-1990). Szczecin: Print Group Daniel Krzanowski s. 33, 83.

Polacy na Łotwie. red. E. Walewander. 1993. Lublin: Wydawnictwo KUL.

Polacy nad Dźwina. red. Fuszara, M. Kurczewski, J. 2007. Warszawa: Wydawnictwo Uniwersytetu Warszawskiego.

Raport o sytuacji Polonii i Polaków za granica, Ministerstwo Spraw Zagranicznych, Warszawa 2013, s. 150.

Samborska-Kukuć, D. 2008. Polski Inflantczyk Kazimierz Bujnicki. Kraków: Collegium Columbinum.

Sozański, J. 2004. Moje Inflanty. Toruń: Wydawnictwo Adam Marszałek.

Stan badań nad wielokulturowym dziedzictwem Rzeczypospolitej t. 3. red. W. Walczak, K. Łopatecki, Białystok: Instytut Badań nad Dziedzictwem Kulturowym Europy, 2012.

Stan badań nad wielokulturowym dziedzictwem Rzeczypospolitej t. 4. red. W. Walczak, K. Łopatecki. Białystok: Instytut Badań nad Dziedzictwem Kulturowym Europy, 2013.

Stan badań nad wielokulturowym dziedzictwem Rzeczypospolitej. t. 1, 2. red. W. Walczak, K. Łopatecki. Białystok: Instytut Badań nad Dziedzictwem Kulturowym Europy, 2010.

Szuba, Z. Polska opieka duszpasterska na Łotwie po II wojnie światowej. [w:] Polacy na Łotwie. red. E. Walewander. Lublin: Redakcja Wydawnictw KUL 1993 s. 277-302.

Ulrińska, M. M., Jurzysta, K. 1994. Szkolnictwo polskie na Łotwie. Toruń: Wydawnictwo Uniwersytetu Mikołaja Kopernika s. 114, 116.

Urlińska, M. M. 2007. Szkoła polska na obczyźnie wobec dylematów tożsamościowych. Toruń: Wydawnictwo Uniwersytetu Mikołaja Kopernika.

Zajas, K. 2008. Nieobecna kultura: przypadek Inflant Polskich. Kraków: Towarzystwo Autorów i Wydawców Prac Naukowych.

Ziemlewska, A. 2008. Ryga w Rzeczypospolitej Polsko-Litewskiej. Torun: Wydawnictwo Naukowe Uniwersytetu Mikołaja Kopernika.

\section{Źrodła internetowe}

„Bowling” - wspólna zabawa, online: http://ryga.zpl.lv/bowling-wspolnazabawa-2016/ [data dostępu: 08.10.2017].

Ambasada RP w Rydze, Jubileusz Klubu Kultury Polskiej „Polonez” w Rydze, online:

https://www.msz.gov.pl/pl/p/ryga_lv_a_pl1/aktualnosci/jubileusz_klubu_k 


\section{InvestigationesLinguisticae, vol. XLII}

ultury_polskiej__polonez_w_rydze;jsessionid=DC6725A9Fo4B5B3AF2FE F682Bo44D25D.cmsap2p?printMode=true [data dostępu: 22.10.2016].

Ambasada RP w Rydze, Odznaczenie dla Pana Edwarda Fiskowicza, online : https://www.youtube.com/watch?v=-JpZl6lfvaQ [data dostępu: 12.10.2016].

Fiskowicz, E. Polacy na Wschodzie [w:] Archiwum pamięci mówionej.

Historia Powstania Związku Młodych Polaków na Łotwie - online: http://www.polonia.lv/index.php?lang=2\&cPath=1|3\&txt_id=2 [data dostępu: 29.10 2016].

http://ryga.zpl.lv/o-nas/ryski-oddzial-zpl/ [data dostępu: 17.10.2016.]

http://www.audiohistoria.pl/web/index.php/swiadkowie/osoba/id /2477/from/szuk , [data dostępu: 12.07.2017].

http://www.grani.lv/tags/akcenty+polskie/ [data dostępu: 17.10.2016].

http://www.hoover.org/news/hoover-archives-acquires-papers-latviandissident-janis-jahimovics [data dostepu:10.11.2017].

http://www.polinfo.lv/ [data dostępu: 12.06.2017].

http://www.polska.lv/info/ [data dostępu: 12.06.2017].

J. Gribule, Edward Fiskowicz - in memoriam [w:] Akant; http://akant.org/archiwum/184-swiat-inflant/swiat-inflant-2017/swiatinflant-2017-nr-2/5774-jolanta-gribule-edward-fiskowicz-in-memoriam [data dostępu: 04.03.2018].

Latvijas poḷu nevalstisko organizāciju ilgtermiṇa sadarbības modelis, Par materiāla saturu atbild biedrība „Latvijas Poḷu biedrība POLONEZ”, http://www.sif.gov.lv/nodevumi/nodevumi/5148/SM_Polu\%20NVO_last.pd f, [data dostępu: 28.06.2017].

Latvijas poḷu nevalstisko organizāciju ilgtermiṇa sadarbības modelis, Par materiāla saturu atbild biedrība „Latvijas Polıu biedrība POLONEZ”, http://www.sif.gov.lv/nodevumi/nodevumi/5148/SM_Polu\%20NVO_last.pd f, [data dostępu: 28.06.2017].

Lebedek, R. Prezydent Polski gościem Polonii łotewskiej, „Polak na Łotwie” 2007, nr 2, http://www.polak.lv/8o/wizyta.shtml. [data dostępu: 12.10.2016].

Lebedek, R. Żegnaj Panie Michale, [w:] Polak na Łotwie, nr 1 (87) 2009; http://www.polak.lv/87/redakcja.shtml. [data dostępu: 05.10.2017].

Malzuba, D. Trzydzieści lat działalności Klubu Kultury Polskiej „Polonez”, online: http://www.polonia.lv/news.php?lang=2\&cPath=1\&new_id=213 [data dostępu: 10.10.2016]. 


\section{Monika Michaliszyn: Mniejszość polska w odrodzonej Łotwie}

Otocki, T. Ostatnie pożegnanie dyrektor szkoły polskiej $w$ Rydze, http://zw.lt/swiat/ostatnie-pozegnanie-dyrektor-polskiej-szkoly-w-rydze/ [data dostępu: 08.10.2017].

Otocki, T. Teraz nie ma już $w$ Dyneburgu takiego entuzjazmu dla polskości. Wywiad z K. Kunicka: http://zw.lt/opinie/krystyna-kunicka-teraz-juz-niema-w-dyneburgu-takiego-entuzjazmu-dla-polskosci/ [data dostępu: 15.07.2017].

Odznaczenia dla zasłużonych przedstawicieli polskiej społeczności na Łotwie. http://www.prezydent.pl/aktualnosci/ordery-iodznaczenia/art,284,zasluzonychprzedstawicieli-spolecznosci-polskiej-nalotwie.html [data dostępu: 06.07.2018].

Polacy $w$ Inflantach. Pamięć i tożsamość, online: http://mob.starogard.pl/194-starogardgdanski-polacy-w-inflantach-pamieci-tozsamosc [data dostępu: 22.10.2016].

Stankiewicz, R. XVIII Festiwal Kultury Polskiej w Posiniu, online: http://www.polonia.lv/news.php?lang=2\&cPath=7\&new_id=198 [data dostępu: 05.10.2016].

Strautmale, Biuletyn Informacyjny $n r$ 1, online: http://ryga.zpl.lv/biuletyninformacyjny-nr-1-2016/ [data dostępu: 08.10.2016].

Kalczyńska M., Z historii i współczesności Polaków w wielokulturowym Dyneburgu, w krainie Łatgalii, online

https://books.google.pl/books?id=Df98wpm8I_cC\&pg=PA393\&lpg=PA393\& $\mathrm{dq}=\mathrm{hALINA}+$ SZAKIEL\&source=bl\&ots=JJvVUmsAG6\&sig=710VfKOHPlLvfc G-

NJkeHyMiS4k\&hl=lv\&sa=X\&ved=oahUKEwjC7rqlhI3cAhXFFSwKHRdeAvU Q6AEITTAJ\#v=onepage\&q=hALINA\%20SZAKIEL\&f=false [data dostępu: 06.07.2018].

\section{Wywiady:}

Wywiad M. Michaliszyn z byłą prezes Ligi Polskich Kobiet Ingą Pḷociņą, Ryga 2014, źródło: archiwum autorki.

Wywiad M. Michaliszyn z Haliną Glovecką, październik 2016, źródło: archiwum autorki.

Wywiad M. Michaliszyn z Prezes Ryskiego Oddziału ZPŁ A. Liepą, listopad 2016, źródło: archiwum autorki.

Wywiad M. Michaliszyn z V. Mirzajewą, październik 2016, źródło: archiwum autorki.

Wywiad z Ambasadorem RP w Republice Słowenii Pawłem Czerwińskim, w latach w latach 1991-1996 pełniącym funkcję II sekretarza Ambasady RP w Rydze. Lipiec 2018, źródło: archiwum autorki. 